\title{
OPTIMIZING THE REGULATION AND CONTROL OF SPORTS INJURY AND FATIGUE OF WINTER OLYMPIC ICE AND SNOW ATHLETES BASED ON INJURY PREVENTION
}

\author{
OTIMIZAÇÃO DA REGULAÇÃO E CONTROLE DE LESÕES ESPORTIVASE FADIGA DEATLETAS DO GELO EDA \\ NEVE NOS JOGOS OLÍMPICOS DE INVERNO COM BASE NA PREVENÇÃO DE LESÕES
}

\author{
OPTIMIZACIÓN DEL CONTROL DE LESIONES DEPORTIVAS Y FATIGA DE LOS ATLETAS DE HIELO Y NIEVE EN \\ LOS JUEGOS OLIMPICOS DE INVIERNO BASADA EN LA PREVENCIÓN DE LESIONES DEPORTIVAS
}

\author{
Lianhong Ye $e^{1,2}$ (ID) \\ (Public Health Education) \\ Peng $\mathrm{Di}^{1,2}$ (D) \\ (Public Health Education) \\ 1. Qiqihar University Physical \\ Education, Heilongjiang, Qiqihar \\ 161006, China. \\ 2. Hebei Institute of Physical \\ Education, China.
}

\section{Correspondence:}

Peng Di

Qiqihar, Heilongjiang, China. 161006. xzbqzh154fq195@126.com

\begin{abstract}
This study reveals the characteristics and relationship of sports injury and fatigue of the Winter Olympics athletes, and monitors the athletes' psychological condition through case analysis of excellent athletes, and provides empirical evidence for athletes' psychological training and preparation for the physical and mental health services of Winter Olympics. Through questionnaires, literature review and other methods to study the injury situation of Winter Olympics ice and snow athletes, the results show that the proportion of chronic lumbar and knee joint injuries, and repeated muscle strains of Chinese Winter Olympics ice and snow athletes is large, and the cure rate is not high. The preparation activities are neither paid enough attention or sufficient, and the rationality of training plan arrangement is insufficient. The main cause of injury is insufficient understanding of the mechanism of injury and illness among athletes and coaches. Individual elite athletes need to improve their coping skills and pay attention to their psychological fatigue. In view of the sports' psychological characteristics and the problems faced by winter athletes, personalized psychological intervention programs should be formulated.
\end{abstract}

Keywords: Athletic Injuries; Snow Sports; Fatigue.

\section{RESUMO}

O presenteestudo revela as características e a relação de lesões desportivas efadiga de atletas participantes dos Jogos Olímpicos de Inverno, emonitora as condições psicológicas dos atletas através da análise de casos de atletas de alto desempenho, além de apresentar provas empíricas para o treino e a preparação psicológico dos atletas para os serviços de saúde fisica e mental dos Jogos de Inverno. Através de questionários, revisão de literatura e outros métodos de estudo das lesões que acometem os atletas dos Jogos Olímpicos de Inverno, em esportes que envolvem gelo e neve, os resultados mostram queégrande a proporção de lesões lombares crônicas, lesões articulares do joelho e recorrência de distensões musculares, e a taxa de cura não éalta. As atividades de preparação não são suficientemente consideradas e a racionalidade do plano de treinos é insuficiente. A principal causa de lesão é a falta de compreensão dos mecanismos que ocasionam lesões e enfermidades entre atletas etreinadores. Atletas individuais de elite precisam melhorar suas habilidades de enfrentamento e prestar atenção à sua fadiga psicológica. Tendo em conta as características psicológicas desportivas e os problemas existentes entre os atletas dos Jogos de Inverno, programas de intervenção psicológica personalizados devem ser formulados.

Descritores: Traumatismos em Atletas; Esportes na Neve; Fadiga.

\section{RESUMEN}

A través del análisis de casos de atletas de élite, este trabajo revela las características y la relación entre las lesiones deportivas y la fatiga de los atletas en los Juegos Olímpicos de invierno, monitorea el estado psicológico de los atletas y proporciona evidencia empírica para el entrenamiento psicológico de los atletas y la preparación del Servicio de salud física y mental En los Juegos Olímpicos de invierno.Juegos Olímpicos.Los resultados mostraron que la proporción de lesiones crónicas de la cintura y la rodilla y la tensión muscular repetida de los atletas de hielo y nieve en los Juegos Olímpicos de invierno en China era mayor.La tasa de curación no es alta. No se presta suficiente atención a las actividades preparatorias y a la racionalidad del plan de capacitación.La razón principal de la lesión es que los atletas y entrenadores no entienden el mecanismo de la lesión y la enfermedad. Los atletas individuales deben mejorar su capacidad de enfrentamiento y prestar atención a la fatiga psicológica.De acuerdo con las características psicológicas de los atletas de invierno y los problemas existentes, se formula un plan de Intervención Psicológica individualizado.

Descriptores: prevención de lesiones deportivas; atletas de hielo y nieve; lesiones deportivas y fatiga. 


\section{INTRODUCTION}

Ice and snow sports are widely carried out in the world. It is a fashionable sport loved by people all over the world. At the same time, it is dangerous. Skiing is a sport in which people put snowboards on their boots to speed, jump and ski on the snow. It is a highly dynamic and exciting sport.' With the development of ice and snow sports (especially modern competitive skiing), there are more and more sports and more fields. Speed skating is a traditional competitive winter sport in China. A group of elite speed skaters have achieved excellent results in various world speed skating competitions. ${ }^{2}$ Some of our well-known speed skating fans will not be able to play their own functional ability and technical level on the road to the Olympic gold medal zero breakthrough, and they will lose the golden opportunity. ${ }^{3}$ Helpless to say goodbye to the speed skating sports arena, prematurely put an end to his sports career, whether it is a major loss for his individual or the country. ${ }^{4}$ It can be said that the high damage rate of athletes in winter projects seriously affects and restricts the development of winter projects in China. In particular, many excellent athletes are at a peak when their age, physical fitness, skills and psychological quality are at their peak, just because of sports injuries, they lose the opportunity to obtain their best scores. ${ }^{5}$

A random questionnaire survey was conducted among 29 Elite Speed Skaters in China. According to the investigation and literature study of the injuries and illnesses, it is found that the main causes of athletes' injuries and illnesses in speed skating events are inadequate preparatory activities, inappropriate exercise schedule, excessive local load and backward strength training methods. In order to achieve excellent sports results, we must attach great importance to the prevention and treatment of injury. Winter project managers, coaches, scientific researchers and medical workers must be aware of the harmful and destructive effects of sports injuries on athletes and the development of winter events. Take proactive measures to prevent, avoid or reduce the occurrence of sports injuries. The athletes who are responsible for the task are older and have more injuries and injuries, ensuring the normal training and participation of athletes. The treatment and recovery of injuries is particularly important. In view of the previous two empirical studies on biathlon, the current situation of mental fatigue, coping skills and self-confidence with exercise status is rarely discussed. The purpose of this study is to reveal the characteristics of sportsman's self-confidence, mental fatigue, coping skills and their relationship in the winter Olympics, and to monitor the psychological status of athletes through case analysis of elite athletes. The psychological services of the Olympic Games provide an empirical basis.

\section{RELATED WORK}

China's modern competitive skiing began in 1991, and mass tourism and leisure skiing began gradually in the late 20th century. Because al pine skiing is thrilling, beautiful, free, dynamic, attractive, and can be widely used. Therefore, alpine skiing is regarded as the essence and symbol of skiing. It is the first choice and main project of tourist skiing, attracting the active participation of people of different ages, genders and different regions, but it is also the snowstorm project with the largest number of sports injuries. Sports mental fatigue and psychological exhaustion are common among high-level athletes. Mechelen DM believes that sports mental fatigue is a reaction to over-training (psychological and physiological stress), and it is a state in which athletes are difficult to maintain normal training and achieve past performance. And showed some tendency to evade stress. Psychological exhaustion refers to an exhaustive psychophysiological reaction caused by long-term insurmountable exercise stress. It not only damages mental health, but also leads to withdrawal from training. Therefore, we should be aware of the huge threat hidden behind skiing, and study the injury factors and preventive measures of skiing sports injury in depth, so as to reduce and avoid the occurrence of skiing sports injury, so as to make more people participate in skiing sports.

In the competitive sports field, sports performance is affected by physiology, psychology, technology and environment. In order to make breakthroughs in sports performance and develop personal maximum potential, besides daily physical, technical and tactical training, the training of psychological skills is also an important topic in the field of sports training. According to Finch C's research report, China will have 18 million skiers in recent years, representing one sixth of the total number of skiers in the world. Skiing is a sport with more injuries. The number of injuries per 1800 skiing days is a more general standard to measure the number of skiing injuries. Stenling A studied the sequential effects of the response in the survey method and the randomized control crossover in the prevention of motor injury. It is a significant loss for both individuals and the country. With the improvement of athletes' competitive sports, the incidence of sports injuries is also rising. Especially for high-level athletes, the high chance of winning is always accompanied by a large risk of injury. Here, we will focus on the medical security work during the preparations for the Winter Olympics. The task-taking athletes are older and have more injuries and injuries, ensuring that athletes are properly trained and participating, and their treatment and recovery of injuries is particularly important.

\section{ANALYSIS AND DISCUSSION}

Coaches and athletes should have a deep understanding of their thoughts, and they should treat sports training as equally as injury prevention and treatment. It is necessary to establish a preventive consciousness closely combined with the characteristics of the project and the means of training. Scientific training methods can not only improve sports performance, but also is one of the important means to prevent injuries. Strengthen the role of medical supervision to prevent excessive fatigue of athletes and take positive measures to eliminate fatigue. Repeatedly and repeatedly bear strong loads, especially a large number of single loads. Tissues are subjected to long-term and intense mechanical stimulation, which reflexively causes a series of pathological changes, such as systemic and local physiological disorders, biochemical metabolic disorders and morphological structural damage, resulting in strain. Especially excellent athletes. The athletes of the older age group have higher self-confidence. It may be because the younger athletes are younger and the psychological burden is lighter. The older group athletes are more familiar with themselves. They have higher expectations for themselves and society, and for many years. The results of the competition may not satisfy them, so their confidence may be weakened. Therefore, athletes in the younger group will have higher levels of confidence in sports than those in the older group. Physical training arrangements are unreasonable. For example, premature or excessive semi-squatting and half-squatting side-squatting exercises are the causes of injury.

Therefore, a computational model of the musculoskeletal system is needed to provide the relationship between external measurements and internal forces and moments, as shown in Figure 1. Musculoskeletal model technology has been developed and widely used in clinical and biomechanical gait analysis, especially in the study of lower limb dynamics.

Table 1. Regression Analysis of Psychological Fatigue and Coping Skills of Winter Olympics Ice and Snow Athletes on Self-Confidence in Sports Status.

\begin{tabular}{c|c|c}
\hline Variable & Interpretation rate(\%) & Variance \\
\hline Psychological fatigue & 32.45 & 0.98 \\
\hline Self confidence & 35.67 & 0.73 \\
\hline
\end{tabular}




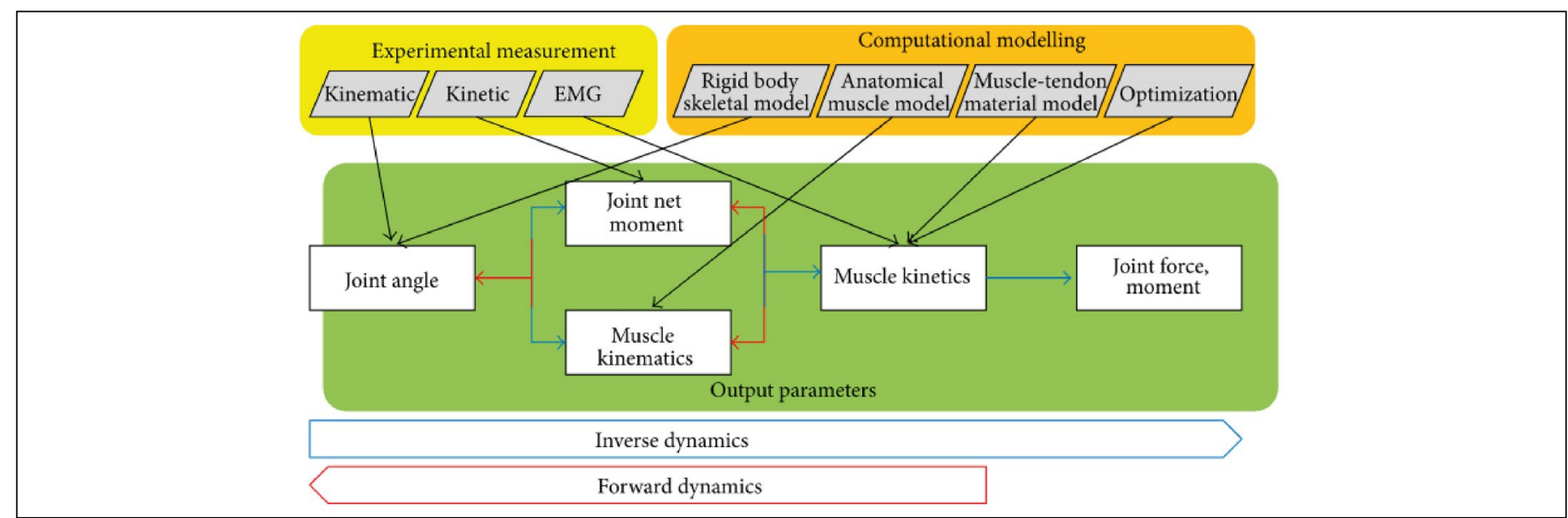

Figure 1. Musculoskeletal model.

There is an information system $D$, where $R$ is a conditional attribute set, $m$ is a decision attribute set and $A$ is a universe, then the resolution formula is:

$$
D\left(p_{1}\right)=A \cdot \frac{m(1-r)}{p_{1}^{b}}
$$

Information system Q, where I is a set of conditional attributes and $D$ is a set of decision attributes. And for any attribute $m>0$, its attribute importance is defined as follows:

$$
A I_{t}=\frac{\left(I_{t}+Q_{t}\right)+\left(I_{t}+Q_{t}-D_{t}\right)}{2}=I_{t}+Q_{t}-\frac{D_{t}}{2}
$$

Where $\mathrm{D}$ is the dependence of decision attribute I on attribute $\mathrm{Q}$, expressed as a positive domain formula:

$$
H_{t}=\frac{\left(I_{t}+Q_{t}\right)}{2} \cdot \frac{\left(I_{t}+Q_{t}\right)}{D_{t}}
$$

The dependence of conditional attributes on decision attributes is transformed into mutual information, and the change of mutual information caused by adding an attribute is taken as a measure of the importance of attributes. The probability distribution is:

$$
f(x)=\operatorname{sign}\left[\omega^{T} x+b\right]
$$

The information entropy of the condition attribute $x$ in the decision table is:

$$
w(t)=w_{2}+\left(w_{1}-w_{2}\right) \frac{T-t}{T}
$$

Entropy of relative condition attribute $P$ of decision attribute $w$ in decision table is defined as:

$$
p= \begin{cases}k & \sigma^{2}<\sigma_{d}^{2}, f\left(P_{g}^{t}\right)>f_{d} \\ 0 & \end{cases}
$$

Assuming that an attribute $n$ is added to the conditional attribute $P$ of the above-mentioned information system k, the increment of mutual information after adding $\mathrm{n}$ is calculated.

$$
e_{j}=-k \sum_{i=1}^{n} f_{i j} \ln f_{i j}
$$

After repeated experiments and comparing the results of many experiments, it is concluded that when the training error is 0.03 and the learning efficiency is set to 0.04 , the prediction effect of reduction results based on mutual information is the best. When the error drops to 0.001 , the curve gradually tends to be flat, indicating that the structure achieves stability and good results. The training process is shown in Figure 2 below.

Information system $\mathrm{W}$, where $\mathrm{k}$ is a set of conditional attributes and $i$ is a set of decision attributes. The attribute subset $j<0$, then the importance of the decision attribute $\mathrm{f}$ is defined as:

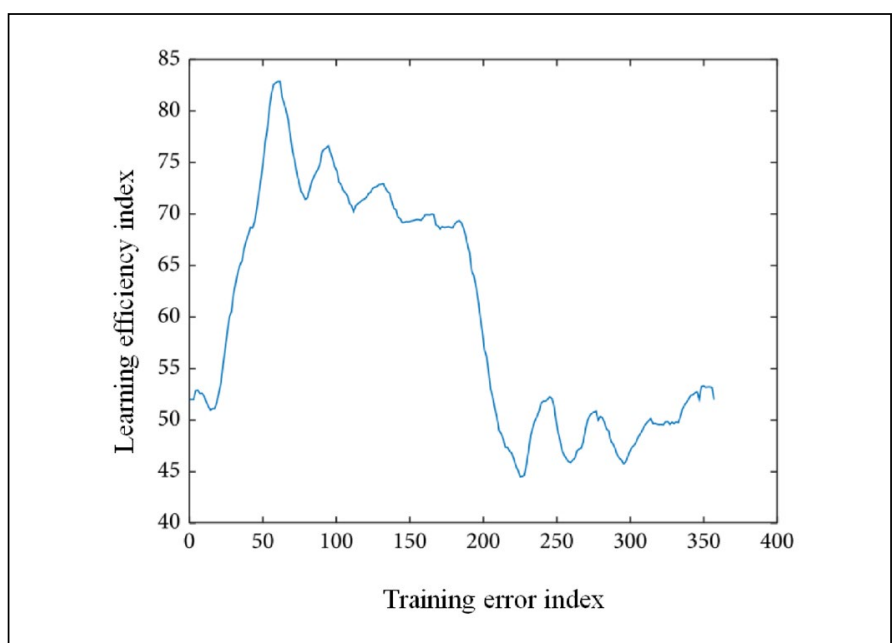

Figure 2. Training process.

$$
W_{j}=1+k \sum_{i=1}^{n} f_{i j} \ln f_{i j} / \sum_{j=1}^{m}\left(1+k \sum_{i=1}^{n} f_{i j} \ln f_{i j}\right)
$$

The value $m$ on attribute $d$ denotes the elements in column J of row I of the discernible matrix. Discernible matrix $\mathrm{W}$ is defined as:

$$
W_{j}=d_{j} / \sum_{j=1}^{m} d_{j}
$$

These values are between $[0,1]$. The function of a group of neurons connected with the first input node is to interpret the K components of the input vector. The output of the neurons is as follows:

$$
a_{k}= \begin{cases}1, & s_{k}>s_{j}, \forall j, k \neq j \\ 0, & \text { Other }\end{cases}
$$

With $m$ rules, the function of the node in this layer is:

$$
w_{i j}=w_{i j}+a\left(\frac{X_{i}}{m}-w_{i j}\right)
$$

The number of nodes in this layer is 1, and the initial value of the 
weight $d$ is set in advance to the rule rough membership value, and the output of the layer node:

$\operatorname{sim}(x, y)=\frac{1}{1+d(x, y)}$

The results of the survey indicate that the injured part of the speed skater is mainly the habitual strain of the lower limb muscle, lumbar muscle strain and soft tissue injury of the knee joint. It shows that the speed skater's injury is mainly caused by special training, as shown in Figure 3.

The response skills of biathlon athletes are at a high level, and the concentration of male athletes is significantly better than that of female athletes, indicating that male athletes may be more able to control their thinking under the conditions of external interference or situational pressure. Women's personality is more delicate, and everything is much more thought-provoking. It is more susceptible to the suggestion and influence of the situation, so it may lead to the distraction of attention and the inability to better control their own thoughts. Pay attention to mobilizing the enthusiasm of athletes. Bring into play the comprehensive advantages of training, scientific research, management, security and ideological and political education "five in one", improve the scientific training level of coaches, and enable athletes to establish correct training modes of technical movement stereotypes and physical, technical, psychological and intelligent coordination development. The role of scientific research in monitoring, controlling and evaluating the training process, exercise load and technical movements should be brought into full play. Ignoring the influence of fatigue training on athletes' physical function, the decline of body immunity, the decline of muscle contraction speed and joint control ability caused by fatigue, and the lack of attention during training are the causes of injury of speed skaters. When making training plans, coaches should arrange training scientifically and reasonably according to the objective indicators of athletes' physical condition and the level of sports skills.

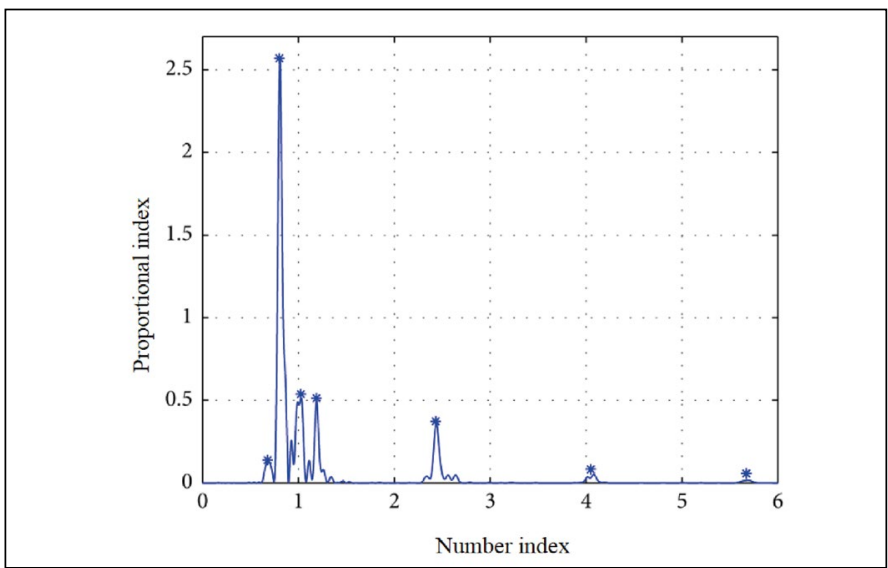

Figure 3. Speed skater injury site statistics.

\section{CONCLUSIONS}

The injuries of ice and snow athletes in the Winter Olympic Games are mainly the habitual strain of lower limb muscles, strain of lumbar muscles and soft tissue injury of knee joint. 96.34\% of the athletes can be treated in time after injury, but the cure rate is only $18.64 \%$, $86.71 \%$ turn to long-term chronic injury. The high incidence of sports injuries seriously affects the training and competition of athletes. The main reasons for the injury of ice and snow athletes in the Winter Olympic Games are inadequate preparatory activities, lack of attention, inadequate mastery of technical movements, weak sense of safety, inadequate training of psychological quality, factors of skiing fatigue or injury, factors of skiing field management, and equipment factors such as skiing clothing and equipment. We should pay enough attention to mental fatigue. In terms of psychological training and intervention, we must continue to consolidate and strengthen athletes'self-confidence training and strengthen stress to cope with psychological counseling. In order to track and monitor the athlete's self-confidence, psychological fatigue, coping skills, etc., the comprehensive effect of mental fatigue and coping skills on self-confidence in sports should be considered. It provides a valuable opportunity for China to develop ice and snow sports. At the same time, it will face more challenges. We should seize the opportunity to find out the problems and gaps in the current development of China's ice and snow sports, and take active and effective measures and means. Let more people know about snow sports and participate in ice sports.

\section{ACKNOWLEDGEMENTS}

2018 Heilongjiang Provincial Department of Education Basic Research Business Expenses Research Project (Humanities and Social Sciences Youth Innovative Talents Project) (Promoting China's Ice and Snow Culture Industry in the Background of the 2022 Beijing Winter Olympics) (135309319), Heilongjiang philosophy and social science research project (Research on the construction path of ice and snow power under the background of 2022 winter olympics) (18TYC236), Heilongjiang provincial ordinary undergraduate colleges and universities young innovative talent training program project (Research on the strategy of building a strong ice and snow country in the context of Beijing 2022) (UNPYSCT-2018110), The research project of philosophy and social science in qiqihar (Study on using ice and snow culture to promote urban development strategy of qiqihar)(QSX2018-09YB)

General Programme of teaching reform in higher education in Heilongjiang (Research on collaborative and innovative development of ice and snow professionals and universities in Heilongjiang under the background of 2022 Winter Olympic Games) (SJGY20190733).

All authors declare no potential conflict of interest related to this articlee

AUTHORS' CONTRIBUTIONS: The author has completed the writing of the article or the critical review of its knowledge content. This paper can be used as the final draft of the manuscript. Every author has made an important contribution to this manuscript. Lianhong Ye, Peng Di: writing and execution.

\section{REFERENCES}

1. O'Brien J, Donaldson A, Barbery G, Finch CF. The three must-do's of intervention reporting: enhancing sports injury prevention research. Br J Sports Med. 2014;48(17):1267-9

2. Kuo-Ming W, Hi-Hsin L, Yi-Ching H. The Knowledge and Attitude of Sports Injury Prevention and Management of Senior High School Athletes in Taiwan. Int J Sport Health Sci. 2012;10:12-22.

3. Talpey SW, Siesmaa EJ. Sports injury prevention: the role of the strength and conditioning coach.
Strength \& Conditioning Journal. 2017, 39(3):14-19.

4. Bekker $S$, Paliadelis $P$, Finch CF. The translation of sports injury prevention and safety promotion knowledge: insights from key intermediary organisations. Health Res Policy Syst. 2017;15(1):25.

5. Delfino Barboza S, Rössler R, Verhagen E. Considerations and Interpretation of Sports Injury Prevention Studies. Clin Sports Med. 2018;37(3):413-5.

\section{Erratum}

In the article entitled "OPTIMIZING THE REGULATION AND CONTROL OF SPORTS INJURY AND FATIGUE OF WINTER OLYMPIC ICE AND SNOW ATHLETES BASED ON INJURY PREVENTION"authored by Lianhong Ye and Peng Di pubished in Rev Bras Med Esporte [online] 2021, vol.27, Special Issue 2. ERRATUM, page 79, by request of the author. - Where it reads:

Correspondence: Heilongjiang, Qiqihar 161006, China. xzbqzh154fq195@126.com

- Read:

Correspondence: Peng Di. Qiqihar, Heilongjiang, China. 161006.xzbqzh154fq195@126.com 